\title{
STUDIES ON GENETIC VARIATION OF FIELD COLLECTED PINK BOLLWORM, PECTINOPHORA GOSSYPIELLA (SAUNDERS) USING RAPD TECHNIQUE Laila E. Seleman
}

${ }^{1}$ Plant protection Research Institute, Agricultural Research Center,Dokki, Giza.

\begin{abstract}
Five strains of the pink bollworm, Pectinophoragossypiella (Sanders)were used in the present study. The laboratory strain was used as a baseline in the molecular biology assays. Four strains were selected from natural populations; fields located in Menoufia, Gharbia, Dakalia and Kafel-Shiekh, Governorates. The molecular studies included the analysis of the plod genomic DNA of the tested strains under this study by using RAPD-PCR method. A battery of five primers was used to evaluate the mutagenic among the sex strains. One primer (C07) generated the highest numbers of fragments, in which the fragments were 25. Four primers (B20, C02, C05 and E07) generated 20,14, 20 and 17 fragments; respectively. The molecular sizes ranged between.152.891 and 1979.767bp. The RAPD patterns resulted from amplification of DNA of the field colony strains and laboratory strain of the pink bollworm, $P$ gossypiella revealed that the lowest value of similarity index was $(0.0 \%)$, which reflects the highest degree of change in DNA structure and sequence between the genomes of untreated pink and those exposed to a wide spread of different insecticides used for controlling the pest in the fields. On the other hand, the four primers $\mathrm{B} 20$ and $\mathrm{C} 02$, recorded similarity index 1.0 between the laboratory strain and Dakahlia\&Kafrel-Sheikh field colony strains; respectively. The primer C02 recorded similarity index 1.0 between Menoufia and Gharbia field colony strains. The primer C05 recorded similarity index 1.0 between Gharbia and Dakahlia field colony strains. Also, the primer $\mathrm{C} 07$ recorded similarity index 1.0 between Gharbia and Kafrel-Sheikh field colony strains. It is interest to note that the less damaging effect to pink bollworm DNA could be attributed to a good detoxifying mechanism developed by the insect as a result of wide spread and long term exposure of insect larvae in additional to different insecticides used in the fields.
\end{abstract}

\section{INTRODUCTION}

The pink bollworm, $P$. gossypiellais one of the most destructive pests of cotton in Egypt. It has been introduced into Egypt between 1903-1913 from India within badly ginned cotton seeds (Willcooks,1916). In 1913, this pest spread to such degree that it became a real danger to the cotton crop in Egypt. It is capable of causing tremendous financial losses of the cotton yield. RAPD-PCR technique helps in genetic analysis of any new species without any prior knowledge about the particular DNA sequences or the genes of these new species. RAPD-PCR technique is not limited to a single locus but theoretically detects polymorphism across the whole genome, either coding or non coding regions in contradiction to biochemical markers which are limited to few genomic regions, so that this method may be used to any mutagen such as insecticides. Different parts of the genome can evolve at different rats (Nei, 1987). It is possible that the regions amplified by PCR evolve at higher rate. Thus RAPD-PCR finger prints can obtain a higher 
variability especially if the amplified regions contain micro or minisatelliteDNA (Baruffiet al., 1995). Amplified fragment length polymorphism was used to detect genetic diversity within and among gypthy moth, Lymantriadisparpopulations (Reineke et al.,1999).Alleloenzyme and RAPD analysis were performed to clarify relationship within the Meligethesviridescenscompex. The M13 RAPD primer is a a diagnostic marker for distinguishing the seven populations of M.spp into four species (Audisio et al.. 2000). Hundsdoerfer and Wink (2005) examined the variability level of the inter simple sequences repeat in the three Lepidoptera families Pyralidae, Sphingidae and Pieridae. They showed the tetra repeat (GACA) is evidently present in sufficient numbers in these butterflies to provide informative DNA fragments. Studies included the analysis of the plod genomic DNA of different field strains of $P$. gossypiellawere carried out by Abdel-Baset (2009) and Abdel-Salam et al. (2013) .They concluded that the arbitrary primers OPA-13, OPA-15 OPA-2, OPA_18, OPB-03, OPC-02, )PD03 and OPE-12 proved to be strong tool to investigate changes in the genomic DNA of the pest. The objective of the present work is to investigate the use of rapid technique to study genetic variation of field collected pink bollworm, P. gossypiella.

\section{MATERIALS AND METHODS}

1. Test insects:

Laboratory strain:

Laboratory strain of the pink bollworm, P. gossypiellawas obtained from the Department of Bollworms Research, Plant Protection Research Institute, Agricultural Research Center, Ministry of Agriculture, Dokki, Giza, Egypt, where it had been maintained on artificial diet consisting of kidney beans. The laboratory strain was used as a baseline in the molecular biology assay.

Field strains:

Five strains of the pink bollworm, $P$. gossypiellawere isolated from Menoufia, Gharbia, Dakahlia and Kafrel- Sheikh Governorates at the late season of 2013 cultivated in different areas as well as temperature conditions and exposed regularly to the recommended insecticidal applications for cotton pests control according to routine schedule program set annually by the Central Administration for Pest Control, Ministry of Agriculture. The cotton fields were treated previously with 4 applications of the recommended insecticides for controlling bollworms representing different groups. These applications are chitin synthesis inhibitors, organophosphates, pyrethroids and organophosphates. These strains were used for molecular biology assay. Rearing technique:

The rearing procedure used in this study was based on artificial diet of kidney bean similar to that described by Abdel-Hafez et al. (1982) with some minor modifications, ten pairs of the newly emerged moths were transferred into glass cages $(750 \mathrm{ml}$ volume, $14 \mathrm{~cm}$ high, $18 \mathrm{~cm}$ upper diameter and $23 \mathrm{~cm}$ lower diameter ) locally named chimney glass No. 5 and stored in an incubator at temperature of $27 \pm 1$ Co, photoperiod of 14:10 (light : 
dark) and relative humidity of $80 \pm 5 \%$. The moths in every cage were fed on $10 \%$ sugar solution that diffused though cotton plugs. The cages were covered with muslin secured with rubber bands and their bottom was covered with screening mesh for stimulating the eggs laying response in the females. The eggs were deposited through the screening mesh on a coarse white papers laced under the cage. The egg sheets were stored under the incubation conditions for 3-4 days until hatching. The newly hatched larvae were transferred using a fine brush to glass tubes $(2 \times 7.5 \mathrm{~cm})$ filled to one third with the larval artificial diet, each vial covered with absorbed cotton and held in the same conditions until pupation. The resulted pupae were held in glass tubes $(4 X 10 \mathrm{~cm})$ covered with muslin and kept at the same incubation conditions until the adult emergence.

\subsubsection{Diet preparation:}

Artificial diet was kidney bean diet prepared according to AbdelHafez et al. (1982).

Molecular genetic studies:

DNA extraction:

DNA isolation (Junhans and metzlatt, 1990)

\section{Buffers}

\begin{tabular}{|c|c|}
\hline \multicolumn{2}{|c|}{ Extraction buffer (pH 8.0) } \\
\hline Tris $-\mathrm{HCl}(50 \mathrm{mM})$ & $10 \mathrm{ml}$ \\
\hline $\mathrm{NaCl}(100 \mathrm{mM})$ & $10 \mathrm{ml}$ \\
\hline EDTA (50 mM) & $10 \mathrm{ml}$ \\
\hline SDS $(0.5 \%)$ & $10 \mathrm{ml}$ \\
\hline \multicolumn{2}{|c|}{ Mercapto ethanol ( $100 \mathrm{ul} / 100 \mathrm{ml}$ solution) was added under hoo } \\
\hline $\mathrm{H}_{2} \mathrm{O}$ up to & $100 \mathrm{ml}$ \\
\hline \multicolumn{2}{|l|}{ TE buffer } \\
\hline Tris (10 Mm, PH 8.0) & $0.121 \mathrm{~g}$ \\
\hline EDTA (1 Mm, PH 8.0) & $0.029 \mathrm{~g}$ \\
\hline $\mathrm{H}_{2} \mathrm{O}$ up to & $100 \mathrm{ml}$ \\
\hline
\end{tabular}

\section{Procedure:}

AGATGCAGCC Polymerase chain reaction (PCR) conditions

PCR- RAPD was conducted using 5 arbitrary 10-mer primers (Operon Technologies, Inc.), The reaction conditions were optimized and mixtures were prepared ( $25-\mu \mathrm{l}$ total volumes) consisting of the following:

\begin{tabular}{|l|c|}
\hline dNTPs $(8 \mathrm{mM})$ & $2.5 \mu \mathrm{l}$ \\
\hline Taq DNA polymerase $(5 \mathrm{U} / \mu \mathrm{l})$ & $0.2 \mu \mathrm{l}$ \\
\hline 10X buffer with $15 \mathrm{mM} \mathrm{MgCl} 2$ & $2.5 \mu$ \\
\hline Primer $(10 \mathrm{mM})$ & $1.0 \mu \mathrm{l}$ \\
\hline Template DNA $(10-20 \mathrm{ng} / \mu \mathrm{l})$ & $1.0 \mu \mathrm{l}$ \\
\hline $\mathrm{H}_{2} \mathrm{O}(\mathrm{dd})$ & $19.3 \mu \mathrm{l}$ \\
\hline
\end{tabular}

Amplification was carried out in StrategeneRobocycler Gradient 96, which was programmed for 40 cycles as follows: 
Denaturation (one cycle) $94^{\circ} \mathrm{C}$ for $4 \mathrm{~min}$, (40 cycles) of the following order $94^{\circ} \mathrm{C}$ for $1.5 \mathrm{~min}, 36^{\circ} \mathrm{C}$ for $1.5 \mathrm{~min}, 72^{\circ} \mathrm{C}$ for $2.5 \mathrm{~min}$ then extension $72^{\circ} \mathrm{C}$ (one cycle) for $7 \mathrm{~min}$.

Table (1): List of RAPD primers and their nucleotide sequences.

\begin{tabular}{|c|c|}
\hline Description & Sequence \\
\hline C02 & 5'- GTG AGG CGT C-3' \\
\hline C05 & 5'- GAT GAC CGC C-3' \\
\hline C07 & 5'- GTC CCG ACG A-3' \\
\hline B20 & 5'- GGA CCC TTA C-3' \\
\hline E07 & 5'- AGA TGC AGC C-3' \\
\hline
\end{tabular}

\section{Gel electrophoresis (Sambrooket al., 1989)}

Agarose (1.2\%) ultra pure (GIBCOBRL) was used for resolving the PCR products One Kb plus DNA ladder (750 $\mathrm{ng} / 3 \mu \mathrm{l}$ ) (GeNetBio) was used which was separated into fourteen bands with molecular weights of 100,200 , $300,400,500,650,850,1000,1650,2000,3000,4000,5000$ and $12000 \mathrm{bp}$.

\begin{tabular}{|l|c|}
\hline \multicolumn{2}{|c|}{ TAE buffer (50X) } \\
\hline Tris & $242 \mathrm{~g}$ \\
\hline Glacial acetic Acid & $57.1 \mathrm{ml}$ \\
\hline EDTA & $37.2 \mathrm{~g}$ \\
\hline dd $\mathrm{H}_{2} \mathrm{O}$ & up to $1 \mathrm{~L}$ \\
\hline
\end{tabular}

\begin{tabular}{|l|l|}
\hline TBE buffer (10X) & $108.00 \mathrm{~g}$ \\
\hline Tris & $55.00 \mathrm{~g}$ \\
\hline Boric acrid & $7.44 \mathrm{~g}$ \\
\hline EDTA & up to $1 \mathrm{~L}$ \\
\hline $\mathrm{d} \mathrm{H}_{2} \mathrm{O}$ & \\
\hline
\end{tabular}

\begin{tabular}{|l|c|}
\hline Gel preparation & $1.2 \mathrm{~g}$ \\
\hline Agarose & $100 \mathrm{ml}$ \\
\hline TAE buffer $(1 \mathrm{X})$ & $1.5 \mu \mathrm{l}$ \\
\hline Ethidium bromide $(10 \mu \mathrm{g} / \mu \mathrm{l})$ & Loading buffer $(6 \mathrm{X})$ \\
\hline & $0.25 \mathrm{~g}$ \\
\hline Bromophenol blue & $0.25 \mathrm{~g}$ \\
\hline Xylene cyanol & $100 \mathrm{ml}$ \\
\hline Glycerol (30\%) & $20 \mu \mathrm{l}$ \\
\hline & $5 \mu \mathrm{l}$ \\
\hline PCR- product & Sample preparation \\
\hline Loading buffer $(6 \mathrm{X})$ & \\
\hline
\end{tabular}

The run was performed for $1 \mathrm{~h}$ at $100 \mathrm{~V}$ using Biometra gel electrophoresis submarine $(20 \mathrm{~cm} \times 10 \mathrm{~cm})$. Bands were detected on UVtransilluminator and photographed by Gel documentation system (Biometra Bio Doc Analyze 2000). 
Analysis of gel images

All DNA electrophoretic patterns were analyzed by EgyGeneGelAnalyzer version three software to determine relative mobility (RF), molecular size by base pairs (bp) and presence (1) or absence (0) of each fragment (http://www.geocities.com/egygene).

\section{Similarity index:}

The similarity index was used to compare patterns within as well as between populations. This index reflects the extent of band sharing and calculated as:

$2 \mathrm{Nab} /(\mathrm{Na}+\mathrm{Nb})$

Where, $\mathbf{N a b}$ is number of bands common to individuals $a, b$.

$\mathrm{Na}$ and $\mathbf{N b}$ are total number of bands in a and $\mathrm{b}$, respectively.

\section{RESULTS AND DISCUSSION}

After PCR amplification, the number and size of fragments may differ between strains. The specific patterns of the DNA observed represent the genetic make-up of each strain. Identical sized bands observed between different strains indicate genetic relatedness or similarity. The $4^{\text {th }}$ instar larvae of the laboratory strain as well as field colony strains of the pink bollworm, Pectinophoragossypiella showed differences in RAPD-PCR patterns of amplified genomic DNA.

Random amplified polymorphic DNA polymerase chain reaction (RAPDPCR) of five colony strains of $P$. gossypiella collected from differenGovernorates:

Five primers of arbitrary sequences were used to screen pooled genomic DNA of the different five strains.

In the $4^{\text {th }}$ instar larvae of $P$. gossypiella, the fingerprints generated by both $\mathrm{B} 20$ and $\mathrm{C} 05$ revealed monomorphic, unique and polymorphic profiles for the pest strains; whereas the fingerprints generated by E07 revealed unique and polymorphic for the pest strains in terms in number and position of RAPD fragments. The fingerprint generated by $\mathrm{C} 02$ revealed polymorphic for the pest strains in terms in number and position of RAPD fragments. On the other hand, the fingerprint generated by $\mathrm{C} 07$ revealed polymorphic and monomorphic for the pest strains in terms in number and positionof RAPD fragments. These primers gave good amplification with distinct fragments.

Primer C07 showed the largest number of RAPD fragments where 25 bands were produced in the five strains of the pest under investigation. (Table 2 and Fig. 1). There were 7, 4, 3, 6 and 5 bands in the laboratory strain, Menoufia, Gharbia, Dakahlia and Kafrel-Sheikh strains respectively. The two fragments of 316.607 and 202.479 bp were shared all strains under investigation. Also, the fragment of $431.091 \mathrm{bp}$ was shared in three strains of four colony strains in addition to the laboratory strain. Two amplified fragments of the laboratory strainas well as the four field colony strains were detected in the $4^{\text {th }}$ instar larvae homogenatesas.

Two fragments of 1902.799 and 1249.708 bp were shared between the laboratory strain and both Dakahlia and Kafrel-Sheikh field colony strains. 
A fragment of 692.254 bp was shared in the laboratory strain, and KafrelSheikh field colony strains.

The similarity index ranged between 0.60 and 1.00 (Table 3). The Rapd-PCR pattern produced by amplification of the $4^{\text {th }}$ instar larvae DNA with primer C07contained a total of 25 bands (Table 2). The number of DNA fragments ranged from 3-7 bands.

The PCR patterns resulted from using Primer B-20 discriminated between the laboratory and four field colony strains. Most of amplified fragments of the laboratory strain were not detected in all field colony strains. Majority of the fragments was noticed in Gharbia field colony strain, where seven fragments were detected. Using primer B-20 revealed some variability between the five different strains of $P$. gossypiella.

The fingerprints generated by primer B-20 revealed polymorphic profiles for each strain in addition to unique profiles for Gharbia and Dakahlia field colony strains of $P$. gossypiella in terms in number and position of RAPD fragments.

The total number of amplified fragments generated by this primer was 20 bands. There were 4, 2, 7,4 and 3 in the laboratory strain, Menoufia, Gharbia, Dakahlia and Kafrel-Sheikh field colony strains (Table 4 and fig. 1). Only one band of $158.754 \mathrm{pb}$ was shared in laboratory and the field colony strains. Another band of $288.981 \mathrm{pb}$ was shared in the laboratory and the field colony strains except Menoufia field colony strain. Moreover, two bands of 512.625 and 197.204 bp fragments were found in Gharbia field colony strain. Another band of $360.829 \mathrm{bp}$ fragment was shared in the laboratory strain and the field colony strain except Kafrel-Sheikh field colony strain. One band of $421.289 \mathrm{bp}$ fragment was shared in the laboratory, Gharbia and Dakahlia strains.

As illustrated in (Table 5), the values of similarity index were ranged from 0.40 to 1.00 . The highest value 1.00 was appeared between the laboratory and Dakahlia strains. The lowest similarity index values 0.40 was appeared between Menoufia and Kafrel-Sheikh field colony strains.

Primer $\mathrm{C} 02$ showed the lowest number of fragments where 14 bands were detected in the five strains under this investigation of pink bollworm, $P$. gossypiella larvae(Table 6 and Fig.1). There were 2, 3, 3, 4, and 2 bands in the laboratory strain, Menoufia, Gharbia, Dakahlia and Kafrel-Sheikh strains; respectively.

The finger prints generated by the primer $\mathrm{C} 02$ revealed polymorphic profiles for the five strains in terms in number and position of RAPD fragments.

Fragment of 152.891 bp was detected in the different strain except Kafrel-Sheikh field colony strains; whereas the fragment 608.616 was appeared in all field colony strains of the pest. On the other hand, the fragment $879.696 \mathrm{pb}$ was detected in the field colony strain except KafrelSheikh field colony strain. The fragment of 270.980 bp was shared in the laboratory strain as well as Dakahlia and Kafrel-Sheika field colony strains. 
J. Plant Prot. and Path., Mansoura Univ., Vol.5 (4), April, 2014

F1 
Laila E. Seleman

2-3-4 
J. Plant Prot. and Path., Mansoura Univ., Vol.5 (4), April, 2014

5- 6-7 
The RAPD-PCR patterns produced by amplification of $P$. gossypiellaDNA with primer C02 contained a total of 14 bands (Table 6 and Fig. 1). The number of DNA fragments ranged from 2-4 bands

As shown in Table (7), the similarity index values were ranged between 0.40 and 1.00 .

Table(8):Total number and size of RAPD-PCR fragments generated by primer Co5 in different strains of $P$. gossypiella larvae.

\begin{tabular}{|c|c|c|c|c|c|c|c|c|c|c|c|}
\hline \multicolumn{2}{|l}{ Laboratory } & \multicolumn{2}{|c|}{ menoufia } & \multicolumn{2}{|c|}{ gharbia } & \multicolumn{2}{c|}{ dakahlia } & \multicolumn{2}{|c|}{$\begin{array}{c}\text { Kafrel- } \\
\text { sheikh }\end{array}$} & $\begin{array}{c}\text { Total no. } \\
\text { of DNA } \\
\text { fragments }\end{array}$ & Polymorphism \\
\hline No. & size & No. & size & No. & size & No. & size & No. & Size & \\
\hline 3 & - & 4 & - & 5 & 1979.767 & 5 & 1979.767 & 3 & - & 20 & polymorphic \\
\hline & - & & - & & 1341.876 & & 1341.867 & & - & & polymorphic \\
\hline & - & & - & & 867.098 & & 867.098 & & - & & polymorphic \\
\hline & 560.304 & & 560.304 & & 560.304 & & 560.304 & & 560.304 & & monomorphic \\
\hline & - & & 329.075 & & - & & - & & - & & unique \\
\hline & 279.369 & & 279.369 & & - & & - & & 279.369 & & polymorphic \\
\hline & 173.283 & & 173.283 & & 173.283 & & 173.283 & & 173.283 & & monomorphic \\
\hline
\end{tabular}

As represented in Table (8) and illustrated in Fig.(1),the fingerprints generated by the primer $\mathrm{C} 05$ revealed polymorphic, monomorphic and unique profiles for the five strains in terms in number and position of RAPD fragments.

Two fragment of 560.304 and 173.283 bp were appeared in all strains including the laboratory strain as well as the four field colony strains, also fragment of 279.369 bp was detected in the laboratory strain as well as Menoufiaas and Kafrel-Sheikh field colony strains. Only one fragment of $329.075 \mathrm{bp}$ was detected in Menoufia field colony strain. Three fragments of 1979.767, 1341.876 and 867.098 were appeared only inGharbia and Dakahlia field colony strains.

The fingerprints generated by primer $\mathrm{C} 05$ revealed polymorphic between Gharbia and Dakahlia field colonystrains and between laboratory, Menoufia and Kafrel-Sheikh strains. Also, the primer C05 generated monomorphic profiles for all strains under investigation and unique profile for Menoufia field colony strain in terms number and position of RAPD fragments.

The RAPD-PCR patterns produced by amplification of $P$. gossypiellaDNA with primer C05 contained a total of 20 bands (Table 8 and Fig. 1). The number of DNA fragments ranged from 3-5 bands

The similarity index ranged between 0.44 and 1.00 . The lowest value was 0.44 between Menoufia and both Gharbia and Dakahlia field colony strains; whereas the highest value of similarity index was 1.00 between laboratory and Kafrel- Sheikh as well as between Gharbia and Dakahlia field colony strains (Table 9 ).

The fingerprints in $P$. gossypiella generated by the primer, Eo7 showed differences in RAPD-PCR patterns of amplified genomic DNA, where unique and polymorphic profiles in terms of number and position of RAPD fragments were detected. The primer showed number of RAPD fragments, where 17 bands were produced in the five strains under investigation of $P$. gossypiella(Table 10 and Fig. 1). There were 3, 3, 4, 1 and 6 bands in the 
laboratory strain, Menoufia, Gharbia, Dakahlia and Kafrel-Sheikh field colony strains; respectively. The number of DNA fragments ranged from 1-6 bands

Table(9): Estimated similarity index between the 5 strains of $P$. gossypiella larvae using primer Co5.

\begin{tabular}{|l|c|c|c|c|c|}
\hline Strains & Laboratory & Menoufia & Gharbia & Dakahlia & $\begin{array}{c}\text { Kafel- } \\
\text { sheikh }\end{array}$ \\
\hline Laboratory & - & 0.86 & 0.57 & 0.57 & 1.00 \\
\hline Menoufia & - & - & 0.44 & 0.44 & 0.86 \\
\hline Gharbia & - & - & - & 1.00 & 0.50 \\
\hline Dakahlia & - & - & - & - & 0.50 \\
\hline Kafel-sheikh & - & - & - & - & - \\
\hline
\end{tabular}

Three fragments of $672.747 \mathrm{bp}$ were shared in the laboratory, Dakahlia and Kafrel-Sheikh strains. Also, three fragments of 410.449 bp were shared in laboratory, Menoufia and Gharbia strains. Additionally, three fragments of 283.345 bp were detected in Menoufia, Gharbia and KafrelSheikh field colony strains. Two fragments of 335.179 were shred in Gharbia and Kafrel-Sheikh field colony strains. Fragments of 240.713 bp were shred in all strains except Dakahlia field colony strain. Only one fragment of both 187.093 and 164.537 bp was detected in Kafrel-Sheikh field colony strain.

Table(10):Total number and size of RAPD-PCR fragments generated by primer Eo7 in different strains of $P$. gossypiella larvae.

\begin{tabular}{|c|c|c|c|c|c|c|c|c|c|c|c|}
\hline \multicolumn{2}{|c|}{ Laboratory } & \multicolumn{2}{|c|}{ Menoufia } & \multicolumn{2}{|c|}{ Gharbia } & \multicolumn{2}{|c|}{ Dakahlia } & \multicolumn{2}{|c|}{$\begin{array}{l}\text { Kafrel- } \\
\text { sheikh }\end{array}$} & \multirow{2}{*}{$\begin{array}{c}\text { Total no. } \\
\text { of DNA } \\
\text { fragments }\end{array}$} & \multirow{2}{*}{ Polymorphism } \\
\hline No. & Size & No. & Size & No. & Size & No. & Size & No. & Size & & \\
\hline 3 & 672.747 & 3 & - & 4 & - & \begin{tabular}{|l|}
1 \\
\end{tabular} & 672.747 & 6 & 672.747 & 17 & Polymorphic \\
\hline & 410.449 & & 410.449 & & 410.449 & & - & & - & & Polymorphic \\
\hline & - & & - & & 335.179 & & - & & 335.179 & & Polymorphic \\
\hline & - & & 283.345 & & \begin{tabular}{|l|}
283.345 \\
\end{tabular} & & - & & 283.345 & & Polymorphic \\
\hline & 240.713 & & 240.713 & & \begin{tabular}{|l|}
240.713 \\
\end{tabular} & & - & & 240.713 & & Polymorphic \\
\hline & - & & - & & \begin{tabular}{|l|}
- \\
\end{tabular} & & - & & 187.093 & & Unique \\
\hline & - & & - & & - & & - & & 164.537 & & Unique \\
\hline
\end{tabular}

No major changes in the banding pattern were observed among samples showing polymorphic and unique patterns (Fig.1).

The fingerprints generated by the primer Eo7 revealed polymorphic profiles for laboratory strain and the four field colony strains \& polymorphic profiles in Menoufia and Gharbia as well as in Gharbia and Kafrel-Sheikh field colony strains. Also, polymorphic profiles in Menoufia, Gharbia and KafrelSheikh field colony strains. Unique profile was detected only in Kafrel-Sheikh field colony strain.

The similarity index ranged between 0.00 and 0.86 (Table 11 ). The lowest value was 0.00 between Menoufia and Dakahlia field colony strains as well as between Ghabia and Dakahlia field colony strains whereas the highest value was 0.86 between Menoufia and Dakahlia field colony strains. 
Table(11): Estimated similarity index between the 5 strains of $P$.gossypiella larvae using primer Eo7.

\begin{tabular}{|c|c|c|c|c|c|}
\hline Strains & Laboratory & Menofia & Gharbia & Dakahlia & $\begin{array}{c}\text { Kafrel- } \\
\text { sheikh }\end{array}$ \\
\hline Laboratory & - & 0.67 & 0.57 & 0.50 & 0.44 \\
\hline Menoufia & - & - & 0.86 & 0.00 & 0.44 \\
\hline Gharbia & - & - & - & 0.00 & 0.60 \\
\hline Dakahlia & - & - & - & - & 0.29 \\
\hline Kafel-sheikh & - & - & - & - & - \\
\hline
\end{tabular}

Reviewing aforementioned results, it could be revealed that the banding patterns are created using short oligonucleotide primers (10bp in length) of arbitrary sequence in Random Amplified polymorphic DNA (RAPD) technique. These arbitrary sequences are not specific for a particular gene or DNA sequence, so they are designed to screen the whole genome in general detecting any changes between two or more genomes under comparison. These primers bind the homologous sequence along the genome and PCR amplification only occurs when opposing primer sites are about bp apart. Within a population sample, mutation caused by any stress (e.g. insecticide treatment or different temperature) change the base sequence of primer binding sites, allowing polymorphism to be detected (Williams et al., 1990). The word "random" in the term RAPD may be somewhat misleading in that the only random component is the sequence of a primer rather than the region amplified.

RAPD-PCR technique has several advantages over other methods used for studying genetic variability. These advantages can be summarized as: It helps in genetic analysis of any new specie without any prior knowledge about the particular DNA sequences for the genes of these new species.

It is not limited to a single locus but theoretically detects polymorphism across the whole genome, either coding or non coding regions in contradiction to biochemical (isozymes and protein) markers which are limited to few genomic regions, so that this method may be used for studying mutations among populations exposed to any mutagen.

Different parts of the genome can evolve at different rates (Nei, 1987). Therefore, it is possible that the regions amplified by PCR evolve at higher rate. Thus RAPD-PCR finger prints can obtain a higher variability especially if the amplified regions contain micro or minisatellite DNA (Baruffiet al., 1995).

Because of the small amount of template used in each reaction, this protocol allows for the simultaneous analysis of several primers in a single run. Furthermore, the RAPD-PCR technique does not require the expensive and hazardous use of radioactive nucleotides as in Restriction Fragment Length Polymorphism (RELP) technique (Cenis and Betita 1994).

PCR cycling may be initiated overnight and the products are loaded into a gel and analyzed the following day (Chen et al.,1999).

In RAPD finger printing an oligonucleotide primer amplifies distinct DNA fragments. These fragments are referred to as RAPD markers. The number and size of RAPD markers depend on the complementarily of the 
sequence of a particular primer and template DNA which is characteristic to an individual (Hedrick, 1992 and Williams et al., 1993).

In the present work it was found that DNA of a good quality is a prerequisite to have reproducible results from RAPD-PCR technique. The highest numbers of amplified fragments were 25 resulted from primer $\mathrm{C} 07$, whereas the lowest number of amplified fragments were 14 resulted from primer C02 in P. gossypiellarvaea.

Primers usually do not have the same amplification efficiency.Katanenet al. (1995) found that some primers fail to amplify; others produce too complex banding patterns.

In the present investigation, the genomic DNA of the laboratory strain and field colony strains was screened for DNA damage or sequences changes using five primers of arbitrary sequences. The absence of a fragment from the RAPD pattern of tested insects may be due to changes in DNA sequence of the insect under investigation. The effect of deletion, insertion or breakage at one or both primer annealing sites on a greater distance than can be amplified (Rafalskiet al.1991). RAPD-PCR produced a series of discrete DNA fragments, which typically vary in intensity and range in size from 77-2505 bp(Abdel-Baset, 2009).

The RAPD patterns resulted from amplification of DNA of laboratory \& field colony strains of $P$. gossypiella revealed the lowest value of similarity index $(0.0)$ which reflects the highest degree of change in DNA structure and sequence was recorded between the genomes of the different strains using primer E7. The same findings were reported by Soliman (1997) who found that primers OPA-1, 2 and 3 exhibited a degree of differences that reached 66.71 to $100 \%$ between the genomic DNA untreated and treated med flies. In this field of study, Hundsdoerfer and Wink (2005) examined the variability level of the inter simple sequences repeat in the three Lepidoptera families Pyralidae, Sphingidae and Pieridae. They showed the tetra repeat (GACA) is evidently present in sufficient numbers in these butterflies to provide informative DNA fragments. The present results are accordance with those obtained by Abdel-Baset (2009). She revealed that primers OPA-13, OPA-15 and OPD-5 are strong tools to investigate changes in the $P$. gossypiella and Culexpipiens genomic DNA, probably due to changes in sequences of these primers. The sequence of the primer is known to be the factor for screening DNA or polymorphism. The present study are going in line with those of Lakshmi (2012) who revealed that the $5^{\text {th }}$ instar larvae of silk worm, Anthereaemylitta exposed to low temperatures during winter have shown significant variation in the levels of various bimolecular to cope with heatchock. The obtained results are supported with those published by AbdelSalam et al. (2013). They recorded that the RAPD patterns resulted from amplification of DNA of the field colony strains and laboratory strain of the pink bollworm, $P$. gossypiella fourth instar larvae revealed that the lowest value of similarity index (0.00), which reflects the highest degree of change in DNA structure and sequence between the genomes of untreated pink bollworm larvae and those exposed to a wide spred of different insecticides which used for controlling the pest. 


\section{REFERENCES}

Abdel-Baset, T.T.(2009): Comparative to toxicological and molecular studies on the pink bollworm Pectinophoragossypiella and Mosquito Culexpipiens.

Abdel- Hafez, A.; A.G. Metwally and M.R.A. Saleh (1982): Rearing pink bollworm Pectinophoragossypiella on kidney beans in Egypt (LepidopetraGelechiidae). Res. Bull Fac. Agric., Zagazaig Univ., No. 576, $10 \mathrm{pp}$.

Abdel-Salam, Dalia A.; S.A. EL- Rafai; A.A. Khidr and G.B. El- Saadany (2013): use of RAPD technique to study Genetic variation of field colony collected Pink Bollworm, PectinophoraGossypiella (SAUNDERS) Egypt. J. Appl. Sci., 28(5) 2013.

Audisio, P.; A.de.Biase; P. Romanelli; M.C. Angelici; V. Ketmaier and E.de.Mattheis (2000): Molecular re-examination of the taxonomy of the Meligethesviridescens seeks complex (Coleoptera: Nitidulidae). Biochem.System. And Ecol., 28(1):1-13.

Baruffi, L. ; G. Damiani ;C.R. Gugliclmino ; C. Bandis ; A.R. Malacrida ; J.L. Cenis ; P. Perez and A. Fereess (1995): identification of Aphid (Homoptera : Aphidiae) species and clones by Random Amplified Polymorphism DNA. Ann. Entomol.Soc. Am., 86(5):545-550.

Cenis, J.L. and F. Betita (1994): Application de la technical RAPD-PCR and plymorphica insects. Invet. Agric. ; Prod. Prot. Veg., 9 (2): 289-297.

Chen, X; Romine, C.P.; Tan Q.; Schlagnhufer, B. ; Ospina, G.M.D.; Royes, D.J. and Huff,

D.R. (1999) : PCR- based genotyping of epidemic and pre- epidemic Trichoderma isolates associated with green mold of Agaricusbisorus. Aplle.Envir.Microbial., 65:267-2678.

Hhedrick, P. (1992): Shooting the RAPDs Nature, 355:679-680.

Hundsdoerfer, A. K. and Wink, M. (2005): New source of genetic polymorphisms in Lepidoptera Zeitschrift fur Naturforschung. Section C, Biosciences; 60: 7/8, 618-624.

Junghans, A. and M. Metzlatt (1990). A simple and rapid method for the preparation of total plant DNA, Biotechniques, 8: 176.

Kantanen, J.;.Vikki ; K. Elo and T.A. Maki (1995): Random amplified polymorphis DNA in cattle and sheep. Application for detecting genetic variation. A NIMA . GENET, 26:315-320.

Lakslumi, V. (2012): Studies on biochemical components of the larval haemolemph, fat body and silk gland of trophicaltasar silkworm, Anthereramylitta.Drury(Dada T.v.) European J.OF Experimental Biology, 2(6) : 2238-2242.

Nei, M. (1987):Molecular evolutionary genetics. Colombia Univ., Press New York. PhD. Thesis, Dept. Entomol., Fac.Sci.,Ain shames Univ., Cairo, Egypt.

Rafalski, J.A.; S.V. Tingey and J.G.K. Williams (1991):Markers a new technology for genetic mapping and plant breeding. Ag.Biotich. News and Inform., 3(4) : 645-648. 
Soliman, A.A.I. (1997): New approaches in the MED flay (CeratitisCapittata )conrol and research using sterile insect technique. PhD. Thesis, Dept. Entomol., Fac. Sci., Ain Shames Univ., Cairo, Egypt.

Willcooks, F.C. (1916): The insects and related pest of Egypt. VI. The insect and related pests injuries to the cotton plan. Pt.l. The Pink bollworm. Sultanic.Agric.

Williams, J.G.K.;Hanafey, M.K., Raflski, J. A. and Tiagey, S.V. (1993): Genetic analysis

Using random amplified polymorphic DNA marker. Methods Enzymol, 218:704-740.

Williams, J.G.K.; A.R. Kubellick ; K.J. LIrak ; J.A. Rafalski and S.V. Tingey(1990): DNA polymorphism amplified by arbitrary primers as useful as genetic markers. Nucleic Acid Reserch, 18(22):6531-6535.

دراسـات علـي الاختلافـات الجينيـة بـين السـلالات الحقليـه لـدودة اللـوز القرنقليـه

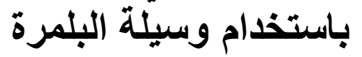
ليلى عباده محمد سليمان البان

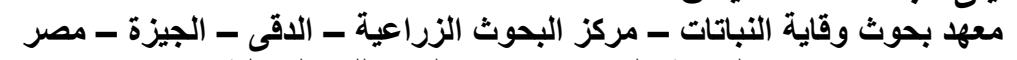

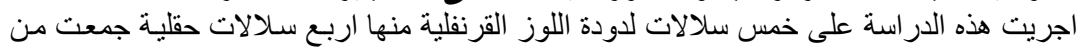

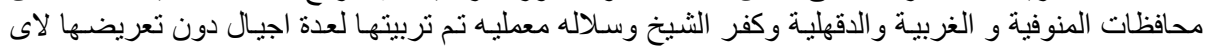

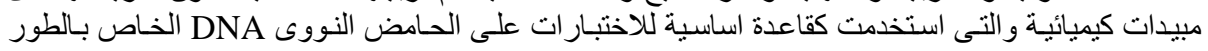

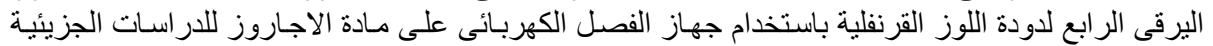

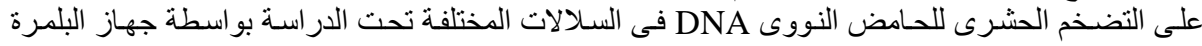

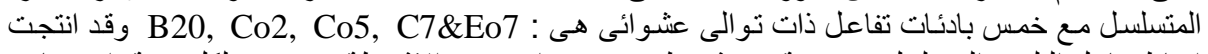

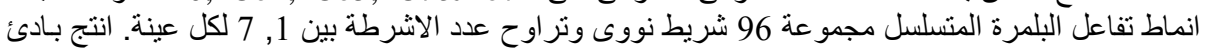

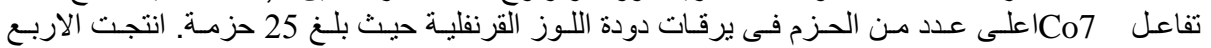
بادئات

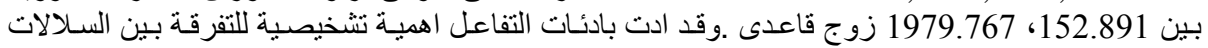

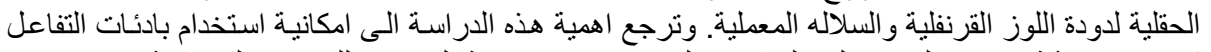

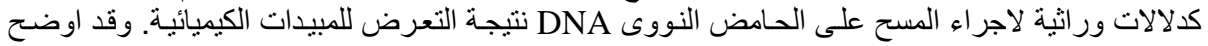

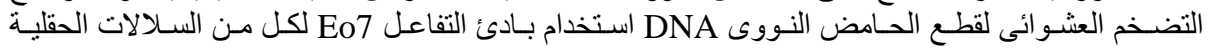

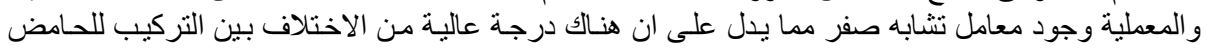

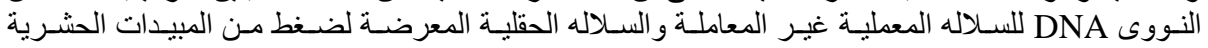

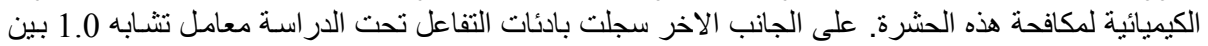

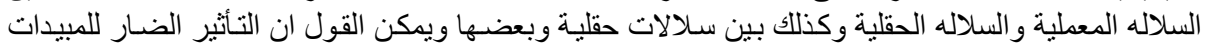

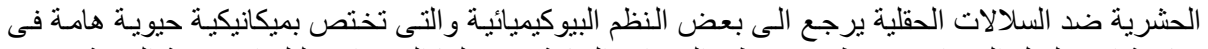

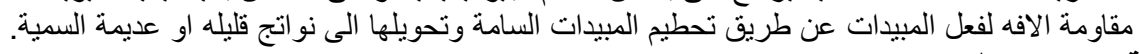

$$
\text { كلية الزراعة - جامعة المنصورة }
$$$$
\text { أ.د / سمير صالح البحث عوض الله }
$$

$$
\text { مركز البحوث الزراعية }
$$

أ.د / مبد العزيز أبو العلا خضر 
Laila E. Seleman 
Table(2):Total number and size of RAPD-PCR fragments generated by primer Co7 in different strains of P.gossypiella larvae.

\begin{tabular}{|c|c|c|c|c|c|c|c|c|c|c|c|}
\hline \multicolumn{2}{|c|}{ Laboratory } & \multicolumn{2}{|c|}{ Menoufia } & \multicolumn{2}{|c|}{ Gharbia } & \multicolumn{2}{|c|}{ Dakhlia } & \multicolumn{2}{|c|}{ Kafrel-sheikh } & \multirow{2}{*}{$\begin{array}{l}\text { Total no. of } \\
\text { DNA } \\
\text { fragments }\end{array}$} & \multirow[t]{2}{*}{ polymorphism } \\
\hline No. & Size & No. & Size & No. & Size & No. & Size & No. & Size & & \\
\hline 7 & 1902.799 & 4 & - & 3 & - & 6 & 1902.799 & 5 & 1902.799 & 25 & Polymorphic \\
\hline & 1249.708 & & - & & - & & 1249.708 & & 1249.708 & & Polymorphic \\
\hline & 842.907 & & - & & - & & 842.907 & & - & & Polymorphic \\
\hline & 692.254 & & 692.254 & & - & & - & & 692.254 & & Polymorphic \\
\hline & 431.091 & & 431.091 & & 431.091 & & 431.091 & & & & polymorphic \\
\hline & 316.067 & & 316.067 & & 316.607 & & 316.607 & & 316.607 & & Monomorphic \\
\hline & 202.479 & & 202.479 & & 202.479 & & 202.479 & & 202.479 & & Monomorphic \\
\hline
\end{tabular}

Table(3): Estimated similarity index between the 5 strains of $\boldsymbol{P}$. gossypiella larvae using primer Co7.

\begin{tabular}{|c|c|c|c|c|c|}
\hline Strains & Laboratory & Menoufia & Gharbia & Dakahlia & Kafel-sheikh \\
\hline Laboratory & - & 0.73 & 0.60 & 0.92 & 0.83 \\
\hline Menoufia & - & - & 0.86 & 0.60 & 0.67 \\
\hline Gharbia & - & - & - & 0.67 & 1.00 \\
\hline Dakahlia & - & - & - & - & 0.73 \\
\hline Kafel-sheikh & - & - & - & - & - \\
\hline
\end{tabular}

Table(4): Total number and size of RAPD-PCR fagments generated by primer B20 in different strains of P.gossypiella larvae.

\begin{tabular}{|c|c|c|c|c|c|c|c|c|c|c|c|}
\hline \multicolumn{2}{|c|}{ Laboratory } & \multicolumn{2}{|c|}{ Menoufia } & \multicolumn{2}{|c|}{ Gharbia } & \multicolumn{2}{|c|}{ Dakahlia } & \multicolumn{2}{|c|}{ Kafrel-sheikh } & \multirow{2}{*}{$\begin{array}{l}\text { Total no. of } \\
\text { DNA } \\
\text { fraqments }\end{array}$} & \multirow{2}{*}{ polymorphism } \\
\hline No. & Size & No. & size & No. & size & No. & size & No. & Size & & \\
\hline 4 & - & 2 & - & 7 & 512.625 & 4 & - & 3 & - & 20 & Unique \\
\hline & 421.289 & & - & & 421.289 & & 421.289 & & - & & Polymorphic \\
\hline & 360.829 & & 360.829 & & 360.829 & & 360.829 & & - & & Polymorphic \\
\hline & 288.981 & & - & & 288.981 & & 288.981 & & 288.981 & & Polymorphic \\
\hline & - & & - & & 248.790 & & - & & 248.790 & & Polymorphic \\
\hline & - & & - & & 197.204 & & - & & - & & Únique \\
\hline & 158.754 & & 158.754 & & 158.754 & & 158.754 & & 158.754 & & monomorphic \\
\hline
\end{tabular}


Laila E. Seleman

Table (5): Estimated similarity index between the 5 strains of P.gossypiella larvae using primer B20.

\begin{tabular}{|c|c|c|c|c|c|}
\hline Strains & Laboratory & Menoufia & Gharbia & Dakahlia & Kafrel-sheikh \\
\hline Laboratory & - & 0.67 & 0.73 & 1.00 & 0.57 \\
\hline Menoufia & - & - & 0.44 & 0.67 & 0.40 \\
\hline Gharbia & - & - & - & 0.73 & 0.60 \\
\hline Dakahlia & - & - & - & - & 0.57 \\
\hline Kafrel-shiekh & - & - & - & - & - \\
\hline
\end{tabular}

Table(6):Total number and size of RAPD-PCR fragments generated by primer $\mathrm{Co} 2$ in different strains of P.gossypiella larvae. \begin{tabular}{|c|c|c|c|c|c|c|c|}
\hline Laboratory & Menoufia & Gharbia & Dakahlia & Kafrel-sheikh & Total no. of & polymorphism \\
\hline
\end{tabular}

\begin{tabular}{|c|c|c|c|c|c|c|c|c|c|c|c|}
\hline \multicolumn{2}{|c|}{ Laboratory } & \multicolumn{2}{|c|}{ Menoufia } & \multicolumn{2}{c|}{ Gharbia } & \multicolumn{2}{c|}{ Dakahlia } & \multicolumn{2}{c|}{ Kafrel-sheikh } & $\begin{array}{c}\text { Total no. of } \\
\text { DNA } \\
\text { fragments }\end{array}$ & $\begin{array}{c}\text { polymorphism } \\
\text { size }\end{array}$ \\
\hline 2 & size & No. & size & No. & size & No. & No. & Size & Polymorphic \\
\hline & - & 3 & 879.696 & 3 & 879.696 & 4 & 879.696 & 2 & - & 14 & Polymorphic \\
\hline & 270.980 & & 608.616 & & 608.616 & & 608.616 & & 608.616 & polymorphic \\
\hline & 152.891 & & - & & - & & 270.980 & & 270.980 & & polymorphic \\
\hline
\end{tabular}

Table (7): Estimated similarity index between the 5 strains of $P$.gossypiella larvae using primer Co2.

\begin{tabular}{|c|c|c|c|c|c|}
\hline Strains & Laboratory & Menoufia & Gharbia & Dakahlia & Kafel-sheikh \\
\hline Laboratory & - & 0.40 & 0.40 & 0.67 & 0.50 \\
\hline Menoufia & - & - & 1.00 & 0.86 & 0.40 \\
\hline Gharbia & - & - & - & 0.86 & 0.40 \\
\hline Dakahlia & - & - & - & - & 0.80 \\
\hline Kafel-sheikh & - & - & - & - & - \\
\hline
\end{tabular}


J. Plant Prot. and Path., Mansoura Univ., Vol.5 (4), April, 2014 